\title{
GEOPROCESSAMENTO APLICADO AO PLANEJAMENTO DA RECUPERAÇĀO DA ÁREA DEGRADADA PELA MINERAÇÃO FLORESTA NEGRA, GUARULHOS, SP
}

\author{
A.B.Macedo \\ M.A.Braghin \\ F.A.F.Salles \\ S.V.Liotte
}

A Mineração Floresta Negra desenvolve atividades de lavra e beneficiamento de areia para construção civil no bairro de Bonsucesso, Município de Guarulhos, SP. A produção média mensal é de $5830 \mathrm{~m}$, e a reserva medida de areia vendável é de $5274000 \mathrm{~m}^{3}$, o que dá à mina 75 anos de vida. A área ocupada pela mineração até agora foi de 17 ha, prevendo-se a mineração de mais 20 ha até o fim da vida da mina, perfazendo 37 ha numa área total de 153,6 ha. A área não minerada será mantida como resenva, por abrigar vegetação em médio e alto grau de regeneração, em um município cuja cobertura vegetal foi muito diminuída pela urbanização.

A mineração apresenta os seguintes problemas ambientais: erosão pela água, nas áreas desmatadas e escavadas e nos tanques de rejeitos já preenchido, que se propõe a controlar pela revegetação e obras de drenagem; erosão pelo vento com geração de poeira: controlada por aspersão de água nas pilhas e revegetação das áreas descobertas; escorregamentos, agora evitados pela lavra em bancadas de pequena altura e que serão controlados pela reconformação do terreno e revegetação na recuperação; alteração no escoamento das águas, que terão seu percurso recomposto na recuperação; deposição de sedimentos: agora controlada por barragens de decantação, no futuro controlados por revegetação; perda de qualidade do solo: mitigada pela recomposição do solo por terra vegetal, correção e adubação, durante a revegetação; desmatamento: mantido ao mínimo durante a mineração, com recomposição da vegetação original na recuperação; impacto visual: controlado por cortinas de vegetação e mitigado pela recuperação.

O Estudo de Impacto Ambiental (Macedo et al., 1991) prevê a recomposição topográfica da área minerada em terraços limitados por taludes com a declividade máxima de 45 graus. Dependendo do planejamento municipal à época do final da vida útil da mina a área recuperada poderá ter utilização para edificação ou ser destinada a reserva. Para que não haja maior degradação

Departamento de Geologia Econômica e Geofísica Aplicada, Instituto de Geociências, USP. 
ambiental prevê-se a recomposição topográfica e revegetação das áreas já mineradas, seguindo-se recuperação concomitante à mineração das parcelas mineradas no futuro. Os trabalhos de recuperação foram iniciados pelo estabelecimento de uma cortina verde em volta da área e estabelecimento de áreas experimentais de revegetação, desde 1991. Com a aprovação do EIA/RIMA em 1993 os trabalhos efetivos de recuperação, antes impossiveis pela incerteza da aprovação do plano. apresentado à SMA há três anos, serão iniciados.

Esta área foi escolhida para um teste de aplicação de geoprocessamento para apoio ao estudo de impacto ambiental, planejamento e execução da recuperação de áreas degradadas.

Está sendo montado um Sistema de Informações Georeferenciadas (SIG), reunindo informações geológicas, geomorfológicas, topográficas, de vegetação, de edificações, equipamentos e atividades de mineração e de fontes de poluição, bem como imagens de sensoriamento remoto e fotografias aéreas.

A primeira parte desta fase foi efetuada como trabalho curricular da disciplina "Mineração e Meio Ambiente", ministrada pelo primeiro autor, sendo digitalizados mapas topográficos e de vegetação. Foi elaborado um Modelo Numérico de Terreno (MNT) e a partir dele calculado um mapa de declividades.

O trabalho continua como atividade de teste de tecnologia e iniciação cientffica. Novos mapas e informações estão sendo digitalizados e está sendo efetuada análise por geoprocessamento para determinação dos processos de controle de poluição e atividades de recuperação adequadas à área, comparando-se os resultados obtidos por geoprocessamento com aqueles determinados durante a elaboração do EIA/RIMA, no qual foram utilizados processos manuais e cálculo de superfícies pelo programa SURFER. Os trabalhos de mineração e recuperação em execução serão acompanhados, aproveitando as possibilidades de atualização imediata dos mapas e bancos de dados, inerentes aos sistemas de geoprocessamento. O sistema utilizado é o IDRISI, que reúne baixo custo, facilidade de operação e treinamento e capacidade suficiente para os trabalhos de digitalização e análise. As ilustrações e mapas finais estão sendo elaborados com os programas Paintbrush e Photostyler.

\section{REFERÊNCIAS BIBLIOGRÁFICAS}

Macedo, A.B. (1991) Recuperação de Áreas Mineradas. In: Fraga, G.P. (coord) Controle Ambiental da Mineração, São Paulo, CETESB, 1991, p. 170-181 (Série Didática, Especial 15).

Macedo, A.B. et al. (1991) Estudo de Impacto Ambiental, Mineração Floresta Negra. Guarulhos, Min. Floresta Negra, 123p. (relatório apresentado à SMA). 